\title{
Spontaneous cervical epidural hematoma mimicking acute ischemic stroke
}

Rahul Rahangdale, MD, John Coburn, MD, and Christopher Streib, MD

Correspondence

Neurology ${ }^{\circledR}$ 2020;95:496-497. doi:10.1212/WNL.0000000000010511

Dr. Rahangdale

rahulrahangdale19@

gmail.com

Figure 1 Cervical spine MRI
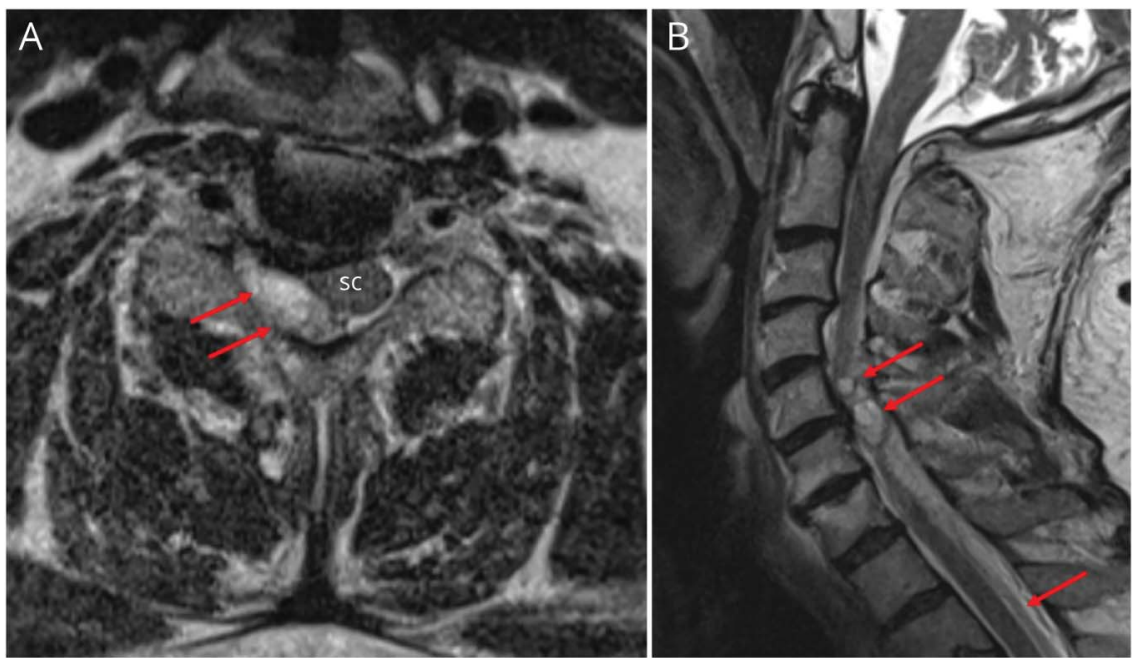

(A) Axial and (B) sagittal T2-weighted images demonstrate hyperintense extramedullary fluid collection (arrows) consistent with spinal epidural hematoma.

A 67-year-old man presented with acute right hemiparesis and hemianesthesia (NIH Stroke Scale score 5). Hyperacute neuroimaging was interpreted as normal. Following IV tissue plasminogen activator, his symptoms worsened, with concern for cervical radiculopathy. Upon

Figure 2 Head and neck CT angiogram (CTA) images
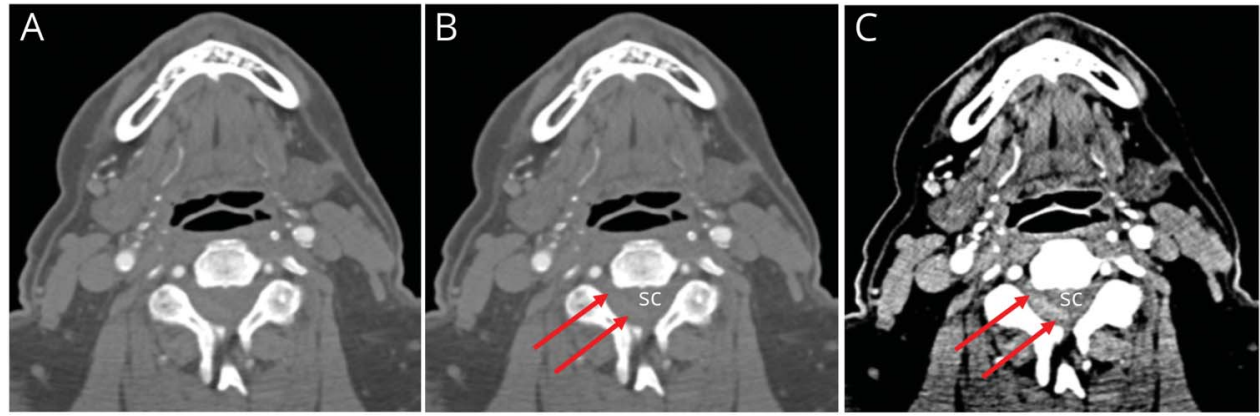

(A) Unlabeled and (B) labeled images with standard CTA window width/level settings and (C) tailored settings optimizing the density differential between epidural hematoma (arrows) and laterally displaced spinal cord (SC).

From the Department of Neurology (R.R., C.S.), University of Minnesota, Minneapolis; and Division of Neuroradiology (J.C.), Midwest Radiology PA, St. Paul, MN. Go to Neurology.org/N for full disclosures. Funding information and disclosures deemed relevant by the authors, if any, are provided at the end of the article. 
reviewing the CT angiogram (CTA), a possible spinal epidural hematoma (EDH) was noted and subsequently confirmed with MRI (figure 1). Cryoprecipitate was administered. His symptoms gradually improved with conservative management. Spontaneous spinal EDH is rare (incidence: $0.1 / 100,000$ per year). ${ }^{1}$ Risk factors include hypertension and coagulopathy. ${ }^{1}$ Although cervical spine EDH is best visualized with MRI, ${ }^{2}$ dedicated attention to the CTA may reveal this uncommon stroke mimic prior to thrombolysis (figure 2).

\section{Study funding}

No targeted funding reported.

\section{Disclosure}

The authors report no disclosures relevant to the manuscript. Go to Neurology.org/N for full disclosures.

\begin{tabular}{lll} 
Appendix & Authors \\
\hline Name & Location & Contribution \\
\hline $\begin{array}{l}\text { Rahul } \\
\text { Rahangdale, } \\
\text { MD }\end{array}$ & $\begin{array}{l}\text { Department of Neurology, } \\
\text { University of Minnesota, } \\
\text { Minneapolis }\end{array}$ & $\begin{array}{l}\text { Study design, acquisition } \\
\text { of data, drafting of the } \\
\text { manuscript }\end{array}$ \\
\hline $\begin{array}{l}\text { John Coburn, } \\
\text { MD }\end{array}$ & $\begin{array}{l}\text { Division of Neuroradiology, } \\
\text { Midwest Radiology PA, St. }\end{array}$ & $\begin{array}{l}\text { Interpretation of data, } \\
\text { critical revision of the } \\
\text { manuscript }\end{array}$ \\
\hline $\begin{array}{l}\text { Paul, MN } \\
\text { Christopher } \\
\text { MS }\end{array}$ & $\begin{array}{l}\text { Department of Neurology, } \\
\text { University of Minnesota, }\end{array}$ & $\begin{array}{l}\text { Study concept, critical } \\
\text { revision of the manuscript }\end{array}$ \\
\hline
\end{tabular}

\section{References}

1. Figueroa J, DeVine JG. Spontaneous spinal epidural hematoma: literature review. J Spine Surg 2017;3:58-63.

2. Pierce JL, Donahue JH, Nacey NC, et al. Spinal hematomas: what a radiologist needs to know. Radiographics 2018;38:1516-1535.

\section{Subspecialty Alerts by E-mail!}

Customize your online journal experience by signing up for e-mail alerts related to your subspecialty or area of interest. Access this free service by clicking on the "My Alerts" link on the home page. An extensive list of subspecialties, methods, and study design choices will be available for you to choose from-allowing you priority alerts to cutting-edge research in your field!

\section{AAN Virtual Fall Conference October 16-17}

Save the date for the first-ever virtual AAN Fall Conference coming to you this October 16-17. The conference will feature timely clinical updates on the hottest topics in the world of neurology, real-world issues in practice management, and innovative science, as well as a prime opportunity to fulfill end-of-year CME requirements. Learn more at AAN.com/20FC.

\section{The AAN is at Your Side}

When you're in the office, the AAN is at your side. The AAN is your \#1 resource to support you and your care team. Whether it's resources to help you and your staff provide the best care for your patients, ensure proper reimbursement, or maximize practice performance, the AAN is at your side. Access these resources today at AAN.com/view/practiceresources. 


\title{
Neurology
}

\section{Spontaneous cervical epidural hematoma mimicking acute ischemic stroke \\ Rahul Rahangdale, John Coburn and Christopher Streib}

Neurology 2020;95;496-497 Published Online before print August 4, 2020

DOI 10.1212/WNL.0000000000010511

This information is current as of August 4, 2020

\author{
Updated Information \& \\ Services \\ including high resolution figures, can be found at: \\ http://n.neurology.org/content/95/11/496.full \\ References \\ This article cites 2 articles, 0 of which you can access for free at: \\ http://n.neurology.org/content/95/11/496.full\#ref-list-1 \\ Subspecialty Collections \\ This article, along with others on similar topics, appears in the \\ following collection(s): \\ All Cerebrovascular disease/Stroke \\ http://n.neurology.org/cgi/collection/all_cerebrovascular_disease_strok \\ e \\ Permissions \& Licensing \\ Information about reproducing this article in parts (figures,tables) or in \\ its entirety can be found online at: \\ http://www.neurology.org/about/about_the_journal\#permissions \\ Reprints \\ Information about ordering reprints can be found online: \\ http://n.neurology.org/subscribers/advertise
}

Neurology $®$ is the official journal of the American Academy of Neurology. Published continuously since 1951 , it is now a weekly with 48 issues per year. Copyright @ 2020 American Academy of Neurology. All rights reserved. Print ISSN: 0028-3878. Online ISSN: 1526-632X.

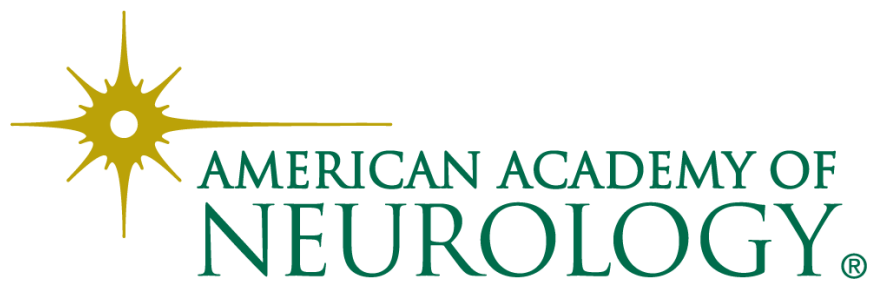

